\title{
5
}

\section{The history of South American octodontoid rodents and its contribution to evolutionary generalisations}

\author{
DIEGO H.VERZI, CECILIA C. MORGAN AND \\ A. ITATÍ OLIVARES
}

\section{Introduction}

The peculiar New World hystricomorph rodents comprise about half of the mammal species of South America (Upham and Patterson, 2012) and have been evolving in this continent for over $40 \mathrm{Ma}$ (Antoine et al., 2012). During this period, they developed an ecomorphological diversity much greater than that of other rodent clades, even when only the extant fauna is considered (Mares and Ojeda, I982; Wilson and Sánchez-Villagra, 20Io; Hautier et al., 2012). This results especially from the evolution of particular morphologies in three of the four suprafamilial clades, Erethizontoidea (New World porcupines), Chinchilloidea (viscachas), and Cavioidea (maras and cavies), a pattern that begins to be apparent in the Oligocene fossil record (Wood and Patterson, 1959; Bertrand et al., 2012). In contrast, the superfamily Octodontoidea has remained morphologically conservative for much longer, the rodents of this group being unique among South American hystricomorphs in retaining a rat-like appearance (e.g. Redford and Eisenberg, I992: pl. I7; Eisenberg and Redford, 1999: pl. 13). Remarkably, when considered in combination with their apparently narrower range of morphological innovation, Octodontoidea is the most diverse clade of hystricomorph rodents. In particular, the families Echimyidae and Octodontidae (including the subfamily Ctenomyinae, considered by neontologists as a family in their own right; see Verzi et al. 2014) comprise more than $60 \%$ of the extant species of South American hystricomorphs, and have the richest fossil record of the suborder (McKenna and Bell, 1997; Woods and Kilpatrick, 2005; Upham and Patterson, 20I2).

The sister families Echimyidae and Octodontidae are two living clades with very different characteristics in terms of geographical distribution and diversity patterns. Echimyidae encompasses a high diversity (i.e. species richness) of small- to middlesized rodents, with arboreal (spiny tree-rats, tree rats, bamboo rats), or terrestrial to fossorial (spiny rats) lifestyles, which occupy Amazonian, coastal and Andean tropical forests in northern South America, and occasionally more open, xeric habitats in the Cerrado and Caatinga (Eisenberg and Redford, 1999; Emmons and Feer, 1999). It also 
includes the semiaquatic coypu Myocastor, an exceptional large-sized representative widely distributed in southern South America. Unlike Echimyidae, Octodontidae is a moderately diversified clade, with the exception of the unusually polytypic tuco-tucos of the genus Ctenomys (Reig, I989). Octodontids are mostly small-sized, terrestrial to fossorial (degus, rock rats, viscacha rats) and subterranean rodents (coruros, tuco-tucos), endemic to mesic and arid biomes of southern South America (Redford and Eisenberg, I992; Ojeda et al., 20I3), with some species possessing significant morpho-physiological adaptations to desert life (Ojeda et al., I999; Ojeda and Tabeni, 2009). [Fossorial and subterranean are used here as defined by Lessa et al. (2008). Fossorial species spend a substantial fraction of their lives outside their burrows, while subterranean ones perform most activities underground. Ctenomys (tuco-tucos) and Spalacopus (coruros) are the only living subterranean South American hystricomorphs.]

These evident adaptive differences and the associated clade-specific distributional patterns are interpreted as resulting from particular evolutionary pathways triggered by late Cenozoic palaeoclimatic changes (e.g. Pascual, 1967; Reig, 1986; Vucetich et al., I999). Since the global late Miocene cooling and drying pulse, octodontids acquired their identity in the increasingly diversified open biomes of the south of South America, whereas the distribution of echimyids became progressively restricted to northern tropical habitats (Pascual, I967; Verzi et al., 1994; Verzi, 2002).

It is unclear how these evolutionary pathways are reflected in the phylogeny and patterns of variation of the group. In this sense, the contribution of fossil evidence is still limited. Partly because of the fragmentary knowledge and frequent morphological resemblance of the oldest (late Oligocene-middle Miocene) remains, there is still no agreement on their meaning regarding the phylogenetic and chronological delimitation of lineages. Many of these early octodontoids have been assigned to Echimyidae, partly because the living species of this family retain lophate, low-crowned molars (Reig, I986; Carvalho and Salles, 2004). In this palaeontological context, Octodontidae has been assumed either as a modern group (Reig, 1986; Vucetich et al., 1999; Arnal and Pérez, 2013), or alternatively as an ancient clade, sister to Echimyidae (Patterson and Wood, I982; Verzi et al., 2014), as interpreted for living species (e.g. Honeycutt, 2009). Furthermore, so that palaeontology can make an operative contribution to the understanding of evolutionary patterns (whichever phylogenetic hypothesis is considered most robust), it is necessary to advance in the recognition of which stages of the evolution of a clade (i.e. origin or differentiation) are represented by fossil evidence. Likewise, given that anagenesis (used here to refer to evolutionary transformation, and not gradual directional evolutionary mode) is not necessarily associated to cladogenesis (Jablonski, 2009; Venditti et al., 20II), attempts to understand adaptive pathways that involve morphological change should not be exclusively focused on the cladogenetic component. Instead, it is necessary to explore evolutionary modes and rates (Simpson, 1953).

Here we present an interpretation of the history of octodontoids based essentially on the evidence provided by the fossil record. We assess the proposal that the different responses of major clades to late Cenozoic palaeoenvironmental changes would result in 
dissimilar phylogenetic structures and patterns of variation reflected in the taxonomic hierarchy of the recognised lineages (Verzi, 2002). In order to do this, we analyse phylogenetic relationships, timing of origin and differentiation of clades, and patterns of variation and disparity. Finally, we discuss the conceptual implications of our approach for more comprehensive evolutionary generalisations.

\section{Materials and methods}

\section{Phylogenetic analysis}

We performed a combined parsimony analysis of extinct and extant octodontoids (Figure 5.I), based on the dataset of 73 morphological characters in Verzi et al. (2014) and five marker sequences obtained from GenBank: two mitochondrial genes (Cytochrome b, II40 bp; I2S rRNA, 932 bp) and three unlinked nuclear exons (GHR, Growth Hormone Receptor exon 1o, 8or bp; vWF, von Willebrand Factor exon 28, II49 bp; RAGI, part of the recombination activating gene, Io64 bp). Sequences of each of the five genes were aligned using CLUSTAL X (Thompson et al., 1997) with the default values of gap opening and gap extension. The dataset of morphological traits was concatenated with the gene sequences, and extinct taxa were coded as missing for all molecular characters. This matrix contained a total of 63 taxa and 5159 characters; Erethizon (Erethizontoidea), Cavia, Cuniculus, Dasyprocta, Dolichotis, Hydrochoerus, Microcavia (Cavioidea), Chinchilla (Chinchilloidea), Abrocoma, Cuscomys and †Spaniomys (Octodontoidea, Abrocomidae) were included as outgroups. The parsimony analysis was conducted treating gaps as missing data in TNT L.I (Goloboff et al., 2008a, b). The heuristic search consisted of to ooo replicates of a Wagner tree with random addition sequence of taxa and followed by TBR branch swapping. In addition, we performed an extra round of TBR on the optimal trees to increase the chance of finding all topologies of minimum length (Bertelli and Giannini, 2005). Zero-length branches were collapsed if they lacked support under any of the most parsimonious reconstructions (Coddington and Scharff, 1994).

The modified Stratigraphic Manhattan Measure (MSM*, Pol and Norell, 20or) was used to integrate the temporal information of fossil record and the resulting phylogeny. Divergence date estimates were based on the first appearance (oldest fossil) confidently assigned to either of the two lineages arising from each branching point. Estimates thus obtained represent minimum constraints on the age of origin of clades (Benton and Donoghue, 2007), and are based on the most reliable date for the oldest levels bearing the indicative fossil. We calculated the MSM* both for the entire tree and for the two major octodontoid clades, with $\mathrm{MSM}^{*}$ values for the latter being comparable owing to the similar number of taxa they contain (Pol et al., 2004).

\section{Patterns of variation and disparity}

We analysed the variation of the skull in lateral view, which allowed us to capture shape changes in the orbit, rostrum, auditory bulla and cranial vault. We used a 


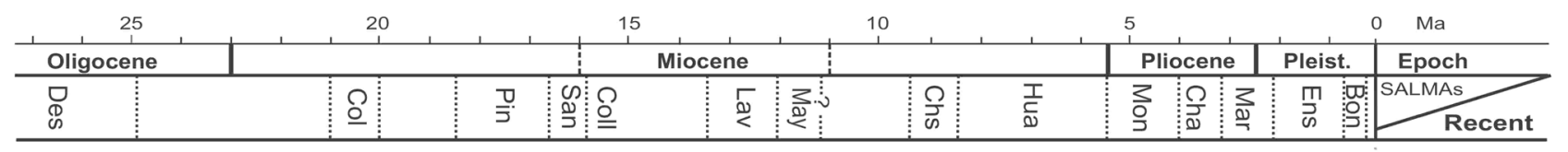

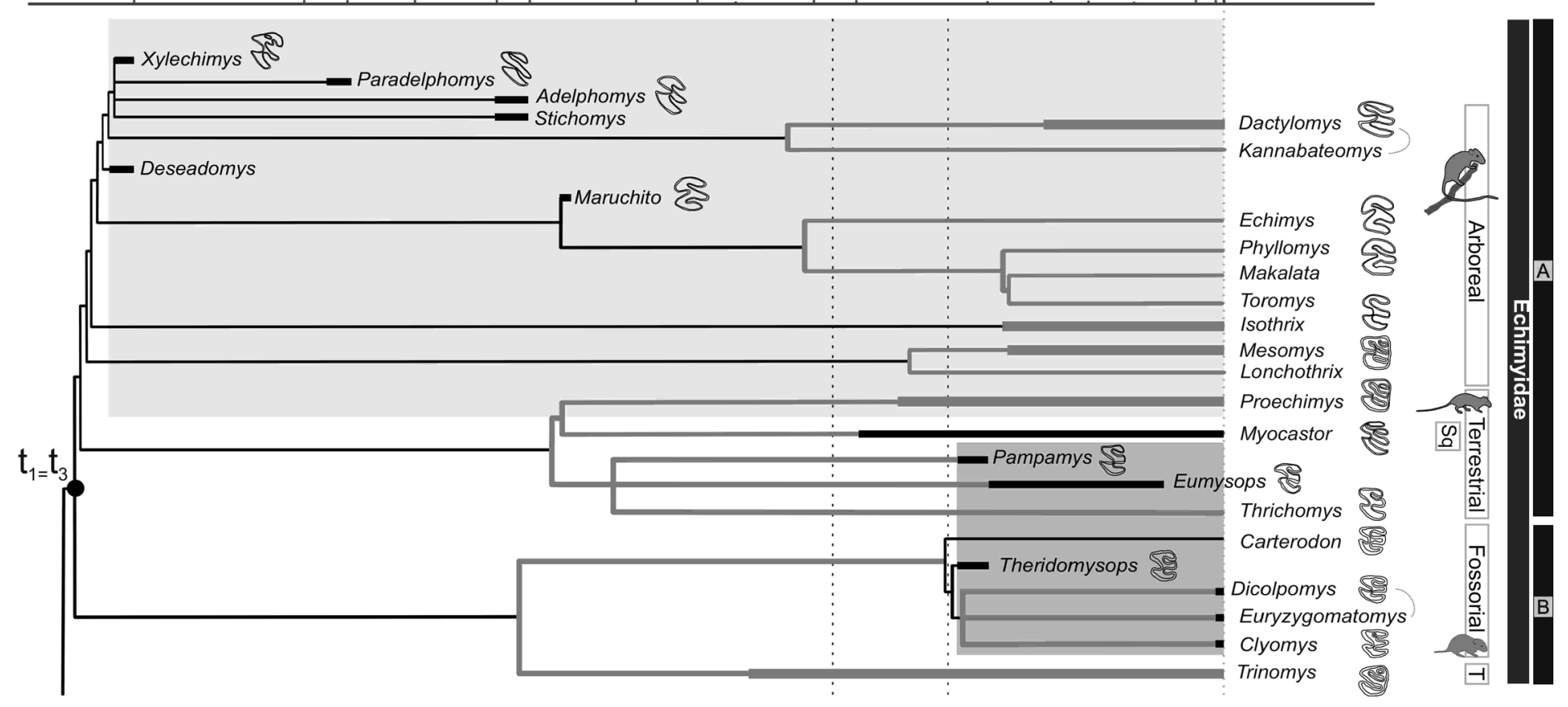

Figure 5.I Most parsimonious tree showing the temporal range and divergence times of octodontoids mapped onto the tree. Black bars are biochrons and grey bars indicate molecular dating of diversification within living genera (after Upham and Patterson, 20I2). Minimum ages of fossils (black lines) are shown when they are older than those from molecules (grey lines). Vertical dashed lines denote the origin of modern ctenomyines and (crown) octodontines for temporal comparisons with branching events within echimyids. Occlusal figures of the left mi or m2 are illustrated next to the corresponding genus (when two figures are presented, the one to the right is ontogenetically more derived). Times of origin ( $\left.t, t_{3}\right)$ and morphological differentiation ( $t_{2}$, modernisation) are indicated for the major clades; the latter stage is represented by the acquisition of euhypsodont molars (black occlusal figures). The light grey shaded background indicates clades of forest-dwellers; dark grey shaded backgrounds indicate clades from more open environments, which are first recorded during the late Miocene global cooling and drying event; dotted background indicates the desert-adapted octodontine subclade, which is first recorded during the late Pliocene-early Pleistocene 

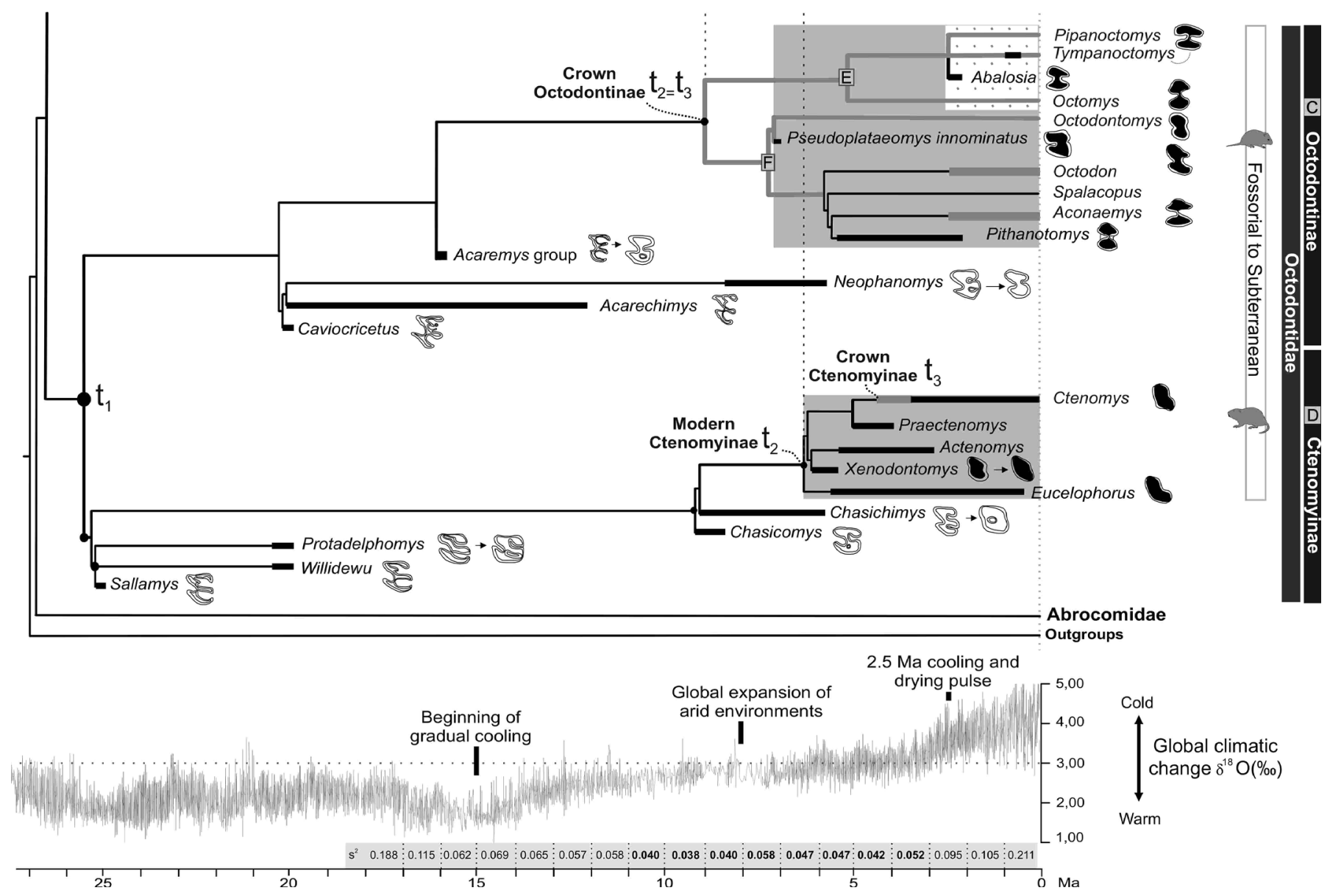

Figure 5.I (cont.) (c. 2.5 Ma) global cooling and drying pulse. Timescale after Gradstein et al. (2008); isotopic curve after Zachos et al. (2008; variance values of oxygen isotope excursions below o.6o are in bold); palaeoclimatic events after Vrba et al. (1995), Denton (r999), Verzi and Quintana (2005), Zachos et al. (2008) and Arakaki et al. (20II). Abbreviations: Bon, Bonaerian; Cha, Chapadmalalan; Chs, Chasicoan; Col, Colhuehuapian; Coll, Colloncuran; Des, Deseadan; Ens, Ensenadan; Hua, Huayquerian; Lav, Laventan; Mar, Marplatan; May, Mayoan; Mon, Montehermosan; Pin, Pinturan; SALMA, South American Land Mammal Age; San, Santacrucian; Sq, Semiaquatic; s2, sample variance; $T$, terrestrial. 


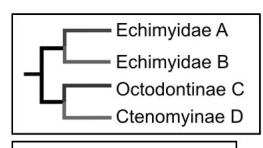

- forest

- open environment

a mixed environment

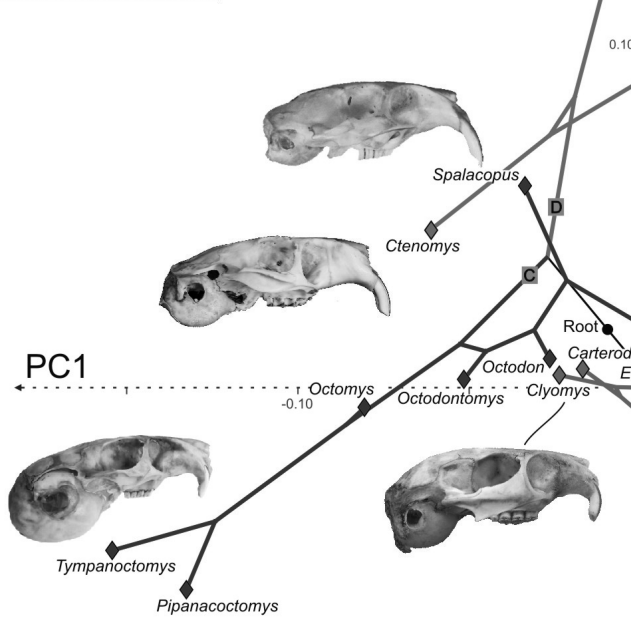

PC2

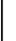
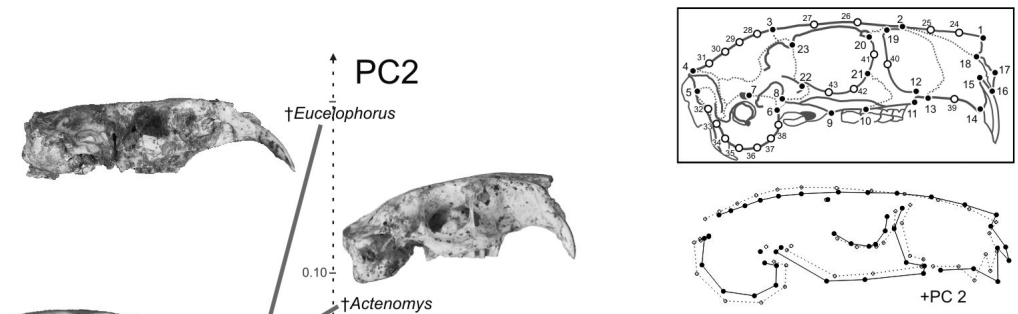

†Actenomys

Myocastor
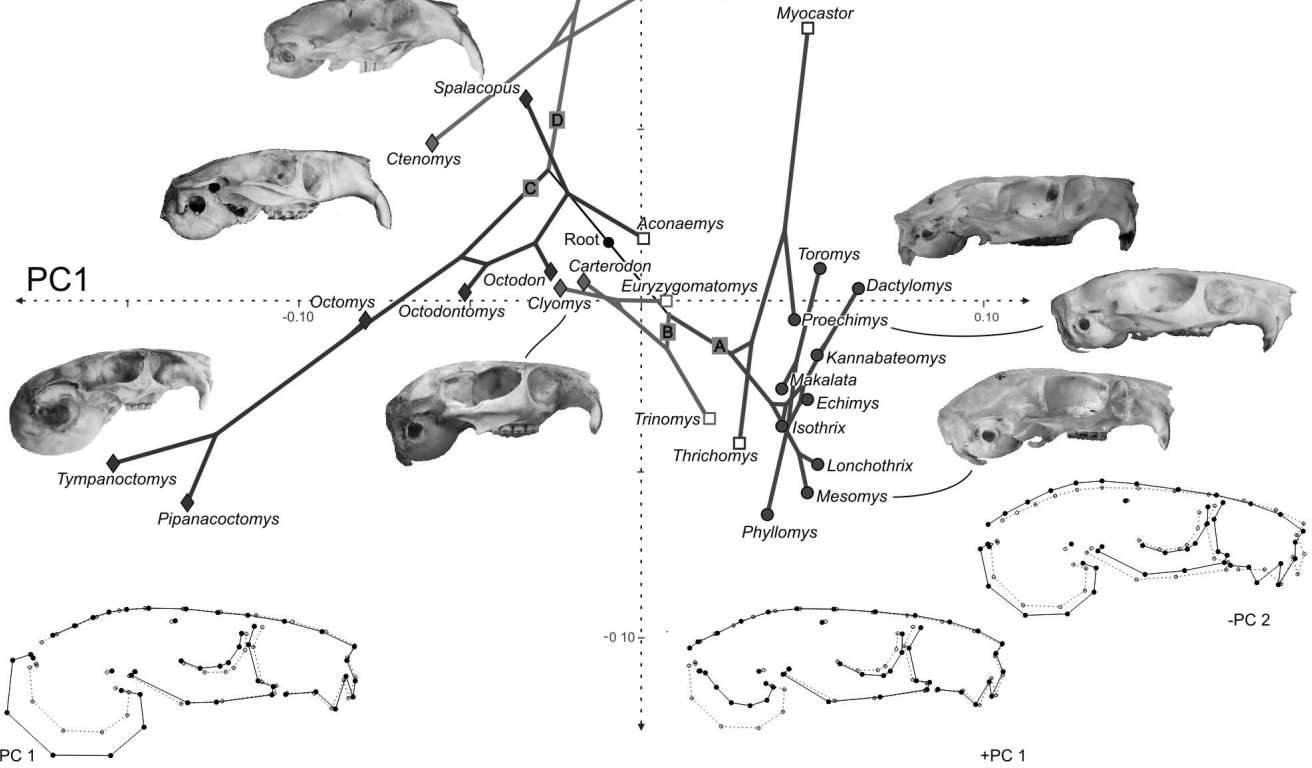

Figure 5.2 Phylogeny tree superimposed onto a plot of the first two principal components (PCs) among the genera analysed. The positions of internal nodes are reconstructed by squaredchange parsimony using the tree topology obtained. At top right, schematic representation of lateral view of skull showing placement of landmarks (solid dots) and semi-landmarks (empty circles). Outline diagrams show shape change associated with each PC, from the consensus (dashed lines and empty circles) to positive or negative scores (black lines and solid dots). Scale factor indicates magnitude of shape change as Procrustes distance. Illustrated skulls not to scale. A black and white version of this figure will appear in some formats. For the colour version, please refer to the plate section.

sample of 167 specimens belonging to 38 species of 26 genera of the families Echimyidae and Octodontidae, the latter including Ctenomyinae (Figure 5.2). Polytypic genera were represented by the following species: Aconaemys porteri, Aconaemys sagei, Ctenomys leucodon, Ctenomys lewisi, Ctenomys magellanicus, Ctenomys mendocinus, Ctenomys talarum, Dactylomys dactylinus, Echimys chrysurus, Isotbrix bistriata, Makalata didelphoides, Mesomys hispidus, Octodon degus, Octodon sp., Phyllomys blainvilli, Proechimys brevicauda, Proechimys poliopus, Proechimys spp., Trinomys albispinus, Trinomys dimidiatus, Trinomys eliasi, Trinomys setosus, Trinomys yonenagae, Thrichomys laurentius. This dataset includes two sufficiently complete remains of the fossil modern ctenomyines $\dagger$ Eucelophorus chapalmalensis and $\dagger$ Actenomys priscus. Two-dimensional 
coordinates were captured on digital images of the skull in left lateral view; for specimens where this side was damaged, the reflected image of the right side was used. A set of 23 landmarks and 20 semi-landmarks (Figure 5.2; description available from the authors upon request) were chosen to capture skull morphology in detail. The $x, y$ coordinates of landmarks and semi-landmarks were digitised using TPSDIG, version 2.I2 (Rohlf, 2008). Semi-landmarks were slid using the minimum bending energy criterion (Bookstein, I997) using TPSRelw I.49 (Rohlf, 2010). The resulting aligned Procrustes coordinates were averaged by genus and the consensus configurations were analysed by Principal Components Analysis (PCA, also known as Relative Warps Analysis) in the software MorphoJ I.05d (Klingenberg, 20II). Shape changes were visualized by means of transformation grids.

Disparity (i.e. morphological diversity; Foote, 1993) for each clade was calculated from the Procrustes coordinates averaged by species, using DisparityBox 7.I4 of the Integrated Morphometrics Package (IMP7, Sheets, 20I0-20I2).

\section{Phylogeny and timescale}

Our analysis resulted in a single most parsimonious tree, 6821 steps long $(\mathrm{CI}=$ $0.42, \mathrm{RI}=0.35$ ) whose topology is essentially (although not strictly) similar to that of previous morphological or molecular trees (Figure 5.I; Honeycutt et al., 2003; Emmons, 2005; Galewski et al., 2005; Verzi, 2008; Upham and Patterson, 2012; Fabre et al., 2013; Verzi et al., 20I4). Octodontoidea is recovered as a monophyletic group, including Octodontidae and Echimyidae as sister clades.

The clade Echimyidae is consistent with the taxonomic definition of this family in the living fauna (Woods and Kilpatrick, 2005) but excludes some of the late Oligocene to middle Miocene genera referred to this taxon in previous studies (Verzi et al., 20I4: table I). Monophyly of the traditionally recognised subfamilies is not supported except for Dactylomyinae. Similar to previous studies, two major subclades are recovered. One of them (here designated as subclade A; Figure 5.I) includes the arboreal representatives, i.e. spiny tree-rats Mesomys-Lonchothrix, brush-tailed rats Isothrix, tree rats Echimys-Phyllomys-Makalata-Toromys, and bamboo rats Dactylomys-Kannabateomys, together with the late Oligocene to middle Miocene fossils $†$ Deseadomys, $\dagger-$ Xylechimys $-\uparrow$ Paradelphomys $-\uparrow$ Adelphomys $-\uparrow$ Stichomys and $\uparrow$ Maruchito. The terrestrial Proechimys and Thrichomys and the semiaquatic Myocastor, along with the late Miocene $\uparrow$ Pampamys and the Pliocene $\dagger$ Eumysops, make up the sister-group of this arboreal clade. The second echimyid subclade (B) groups the extant fossorial spiny rats Carterodon, Clyomys and Euryzygomatomys with the Atlantic spiny rats Trinomys and the late Miocene $\dagger$ Theridomysops and late Pleistocene-Holocene $\uparrow$ Dicolpomys.

The clade Octodontidae of our phylogeny comprises two major subclades that include the traditionally recognised living and extinct Octodontinae and Ctenomyinae, respectively. Neontologists currently consider these two groups as families (Woods and Kilpatrick, 2005; Honeycutt, 2009), but here we retain the name Octodontidae for the more encompassing clade, including both subclades and their more recent common 
ancestor (see Verzi et al., 20I4). Subclade C includes the modern, late Miocene to Recent euhypsodont octodontines along with more ancient fossils with uncertain affinities (†Caviocricetus- $\uparrow$ Acarechimys- $\uparrow N e o p h a n o m y s$, and the $\uparrow$ Acaremys group). Modern octodontines are clustered into two subclades, both encompassing openenvironment species with diverse digging abilities: one of them includes mesic-adapted species plus the desert inhabitant Octodontomys, and the other, desert-adapted representatives (Figure 5.I). The sister subclade, D, includes traditional (modern) ctenomyines, i.e. the living subterranean tuco-tucos (Ctenomys), and the allied euhypsodont late Miocene-Pleistocene species and genera, together with late Oligocene to late Miocene fossils with more conservative, rooted molars, previously considered as echimyids or octodontoids with uncertain affinities ( $\dagger$ Protadelphomys $-\uparrow$ Willidewu$\uparrow$ Sallamys, †Chasicomys and $\uparrow$ Chasichimys).

Age estimations made from the fossils in our phylogeny suggest a late Oligocene age for the divergence between echimyids and octodontids, and between the major lineages included within each of them. Branching within modern (i.e. euhypsodont) octodontines and ctenomyines would have occurred at different times during the late Miocene-Pliocene, with octodontines starting to diversify slightly earlier. A late Pliocene cladogenesis gave rise to the subclade of desert specialists $†$ Abalosia-Tympanoctomys-Pipanacoctomys (Figure 5.I). Also during the Pliocene, the most recent branching event within ctenomyines originated the extant genus Ctenomys.

The overall fit of our phylogenetic hypotheses with the stratigraphic record is low (MSM* score of 0.07 ) implying the existence of substantial ghost-lineages (i.e. lineages that are inferred to occur by the phylogenetic structure but for which there is no fossil record; Norell, I992; Smith, I994). We obtained a similarly low value for echimyids (MSM*: o.I3), most of whose extant lineages are inferred to originate in the Oligocene but are only recorded from the late Miocene or Pliocene onwards. By contrast, our phylogenetic hypothesis for octodontids fits the stratigraphic record somewhat better (MSM*: 0.26). The $\mathrm{MSM}^{*}$ scores for all trees are statistically significant $(\mathrm{P}=0.00 \mathrm{I})$.

\section{Phylogenetic structure and dating of evolutionary stages}

Our fossil-based estimate is consistent with molecular datings in suggesting that the primary echimyid/octodontid split is at least late Oligocene in age. According to molecular estimates, the crown groups of Echimyidae and Octodontidae are younger than this split, suggesting the existence of stem groups not recognised in our analysis (Table 5.I). Even more informative than this inconsistency between fossils and genes, is that both this palaeontological estimate and the molecular ages for the origin of octodontids, octodontines and ctenomyines, exceed previous fossil-based datings (e.g. Reig, I989; Vucetich et al., I999; Vucetich and Kramarz, 2003), largely as a result of differences in the definition of these higher taxa.

The early Oligocene to middle Miocene octodontoids possess recurrent dental morphologies, a fact that has contributed to maintain their systematic and phylogenetic 
Table 5.I. Comparison of estimated ages for origin of total-groups $\left(t_{r}\right)$ and crown-groups $\left(t_{3}\right)$, and modernisation stage (morphological differentiation, $t_{2}$ ) of studied taxa. Values from this study are minimum age fossil-based estimates.

\begin{tabular}{|c|c|c|c|c|c|c|c|c|}
\hline & $\begin{array}{l}\text { This } \\
\text { study }\end{array}$ & $\begin{array}{l}\text { Vucetich } \\
\text { et al. } \\
(\text { I999) }\end{array}$ & $\begin{array}{l}\text { Gallardo } \\
\text { and } \\
\text { Kirsch } \\
\text { (20oI) }\end{array}$ & $\begin{array}{l}\text { Honeycutt } \\
\text { et al. } \\
(2003)^{b}\end{array}$ & $\begin{array}{l}\text { Opazo } \\
(2005)\end{array}$ & $\begin{array}{l}\text { Rowe } \\
\text { et al. } \\
(2010)^{c}\end{array}$ & $\begin{array}{l}\text { Upham } \\
\text { and } \\
\text { Patterson } \\
(2012)\end{array}$ & $\begin{array}{l}\text { Fabre } \\
\text { et al. } \\
(2 \mathrm{OI} 3)^{d}\end{array}$ \\
\hline $\begin{array}{l}\text { Echimyidae } \\
t_{\mathrm{I}}\left(\mathrm{t}_{2}\right)\end{array}$ & $\begin{array}{l}\sim 26.0 \\
\quad(\sim 26.0)\end{array}$ & $>28.0 ?$ & & $27 \cdot 4$ & $\mathrm{I} 7.5$ & $\sim 25.0$ & $25 \cdot 3$ & 27.1 \\
\hline $\begin{array}{l}\text { Echimyidae } \\
\mathrm{t}_{3}\end{array}$ & $\sim 26.0$ & & & & $8.6^{(\mathrm{d})}$ & $15.0^{(\mathrm{d})}$ & I8.8 & 20.5 \\
\hline $\begin{array}{l}\text { Octodontidae } \\
t_{\mathrm{I}}\end{array}$ & $\sim 25.5$ & $>9.0$ & & $27 \cdot 4$ & $\mathrm{I} 7.5$ & $\sim 25.0$ & $25 \cdot 3$ & $27 \cdot I$ \\
\hline $\begin{array}{l}\text { Octodontinae } \\
t_{\mathrm{I}}\left(\mathrm{t}_{2}\right)\end{array}$ & $\begin{array}{l}\sim 25.5 \\
\quad(\sim 7.0)\end{array}$ & $>9.0$ & $25 \cdot 5$ & I9. 6 & I5.O & 22.0 & I9.I & 22.6 \\
\hline $\begin{array}{l}\text { Octodontinae } \\
t_{3}\end{array}$ & $\sim 7.0$ & & 9.0 & 8.6 & 7.8 & 8.0 & 9.0 & \\
\hline $\begin{array}{l}\text { Ctenomyinae } \\
t_{\mathrm{I}}\left(\mathrm{t}_{2}\right)\end{array}$ & $\begin{array}{l}\sim 25.5 \\
\quad(\sim 6.0)\end{array}$ & $>9.0$ & 25.5 & I9.6 & I5.0 & 22.0 & I9.I & 22.6 \\
\hline $\begin{array}{l}\text { Ctenomyinae } \\
\mathrm{t}_{3} \\
\end{array}$ & $\sim 3.5$ & & & & & & $4 \cdot 3$ & \\
\hline
\end{tabular}

${ }^{\text {a }}$ Original chronology updated on the basis of current available information (Verzi et al., 20I4).

${ }^{\mathrm{b}}$ Data as averaged in Honeycutt (2009).

${ }^{\mathrm{c}}$ Calculated using 55 million years as maximum age for Caviomorpha.

${ }^{\mathrm{d}}$ Age estimation based on partial sampling. See references for calibration points and molecular data.

interpretations in a state of flux. As mentioned above, many of these early octodontoids with lophate, low-crowned molars have often been assigned to Echimyidae (Carvalho and Salles, 2004; Verzi et al., 20I4: table I) because living species of the latter have conservative dental designs (Reig, I986). Octodontids have been considered as an offshoot of an unnamed octodontoid stem (which includes echimyids; Reig, I986; Vucetich and Kramarz, 2003; Arnal and Pérez, 2013), and defined through their hypsodont, especially euhypsodont, molars with simplified occlusal surfaces, which characterise their late Miocene-Recent representatives (Figure 5.I). In contrast, the present phylogenetic analysis (see also Verzi et al., 20I4) recovers Octodontidae and Echimyidae as ancient sister monophyletic groups.

Such different interpretations do not derive only from different tree topologies, but also from the implicit or explicit assumption of hypotheses assigning the fossils to particular evolutionary stages of the clades. In this regard, three successive stages can be recognised in the evolutionary history of any clade, referred to as tr, $t_{2}$ and $t_{3}$ by Hennig (I965: fig. 4): tr, its origin, i.e. divergence from its sister clade; t2, its modernisation, i.e. morphological differentiation by acquisition of the apomorphies that characterise its extant members; and $t_{3}$, the origin of the last common ancestor of these living 
representatives (Figure 5.I). Hennig (I965: II4) pointed out that stages tI and $t_{3}$ are two points in time of particular importance in the history of a clade, whereas the delimitation of the stage of modernisation, $\mathrm{t} 2$, depends on subjective criteria concerning the interpretation of the emergence of particular "types" or "Baupläne". We believe that stages $t_{1}, t_{2}$ and $t_{3}$ provide information regarding different processes. The times of origin of a clade ( $\mathrm{tr}$ ) and of its crown group ( $\left.\mathrm{t}_{3}\right)$ represent cladogenesis and extinction; in our case, the period separating tr and $t_{3}$ in both octodontid subclades implies extinction of lineages. The stage $t_{2}$ is related to change within lineages, and although its delimitation may imply subjectivity (which is amenable to description), such differentiation stages can yield important evolutionary information when analysing environmentally driven changes in morphology.

The interpretation of the first records of the derived morphologies of octodontids, octodontines and ctenomyines, as indicators of clade origin, yields ages younger than Io Ma for each of these taxa (Table 5.I; Reig, I989; Verzi, I999; Vucetich et al., I999). Conversely, including stem representatives provides another way of defining and dating these clades. Although more unstable, because stem members are often poorly preserved and/or share few apomorphies with their corresponding crown groups (Briggs and Fortey, 2005), this definition has the advantage of taking into account the deep history of a lineage (Patterson, I993a, b; Donoghue, 2005). Our definitions of Octodontidae, Octodontinae and Ctenomyinae follow this last criterion (Figure 5.I), thus interpreting modern (i.e. euhypsodont) species as representing stages of differentiation characterised by the acquisition of the morphologies occurring in the extant species (t2). These stages are decoupled from the splits that separated these families and subfamilies (tr; Figure 5.I; Steiper and Young, 2008), and, at least in the case of ctenomyines, also from the origin of the crown group ( $\left.t_{3}\right)$. In this latter case, the time of morphological differentiation can only be informed by fossils, highlighting the unique contribution of palaeontology to the appreciation of the true shape of trees (Helgen, 20II) and our understanding of macroevolutionary patterns.

It is noteworthy that, in our interpretation, neither a stage of modernisation $\left(\mathrm{t}_{2}\right)$, nor the origin of crown groups ( $\left.\mathrm{t}_{3}\right)$, are recognisable as stages distinct from the origin (tI) in the case of echimyids and their two main subordinate clades. This major difference with respect to the octodontid pattern can potentially promote explanatory hypotheses.

\section{Patterns of variation and disparity in modern representatives}

Figure 5.2 shows the skull shape variation of living octodontoids and the extinct modern ctenomyines $\dagger$ Actenomys and $\dagger$ Eucelophorus. This variation is represented in the morphospace of the first two axes of a PCA of Procrustes coordinates. These first two principal components (PC) explained $63.3 \%$ of the total variation of our sample. Along $\mathrm{PC}_{\mathrm{I}}$ (36.40\% of total variance), forest-dwelling echimyids are clustered in a relatively restricted space within positive values, while octodontines, ctenomyines, and echimyids from open environments are more scattered in the shape space, most occupying negative values. The desert-specialist octodontines Tympanoctomys and Pipanacoctomys 
have the most extreme negative scores. The main shape changes along this axis involve a larger auditory bulla toward negative values, and a larger orbit toward positive values. Hypertrophy of the auditory bullae, as represented in the negative PCI extreme, is a clear specialisation to desert environments (e.g. Lay, 1972; Ojeda et al., 1999). Along $\mathrm{PC}_{2}$ (26.9\% of total variance), most echimyids and octodontines have negative or nearzero scores, while only the ctenomyines, the octodontine Spalacopus and the echimyid Myocastor show higher positive values. The skulls of the latter present higher zygomatic arches, a lower cranial vault, more retracted nasals, and longer procumbent premaxillae, all of these features being advantageous for digging (e.g. Stein, 2000); to a lesser extent, they also have somewhat smaller bullae.

As Figure 5.2 shows, the forest-dwelling echimyids present lower morphological diversity. The fossorial Euryzygomatomys, Clyomys and Carterodon, and to a lesser extent Trinomys and Thrichomys, which occupy intermediate to more open habitats, are at some distance from the forest dwellers. In particular, the fossorial Carterodon and Clyomys, which inhabit Chacoan environments, occupy positions closer to octodontids.

The position of Myocastor, separated from all other taxa in the morphospace, reflects its atypical features; as previously mentioned, unlike other members of the family this semiaquatic digger occurs widely in the Southern Cone and is the largest living echimyid. Nevertheless, in our analysis body size did not appear to have influence on shape changes; a multivariate regression of shape (all PCs) on size (as centroid size) was significant, but only $15.65 \%$ of the shape variation was predicted by size (10 ooo permutations, $p=0.0035$ ). Accordingly, the distribution of taxa in the morphospace was unrelated to their relative size.

The wide dispersion of octodontids in the morphospace reflects the considerable morphological variation between the desert inhabitants (Octomys, Octodontomys, Pipanacoctomys and Tympanoctomys) on one hand, and the strongly specialised subterranean representatives (Spalacopus, ctenomyines), on the other. Spalacopus shares the morphospace of modern ctenomyines, especially Ctenomys, which is not surprising considering their common subterranean specialisations. $\dagger$ Eucelophorus, the taxon with extreme positive values on $\mathrm{PC}_{2}$, is the South American rodent with greatest craniodental specialisation for digging (Verzi and Olivares, 2006; Vieytes et al., 2007).

As expected, the values of the disparity index (Foote's $F$ ) agree with the results of the exploratory PCA. As shown in Table 5.2, these disparity values are not related to the age or species richness of the clades. Concerning the latter, although our sampling is only partial in the case of highly polytypic genera, the species analysed are representative of the major subclades; this is especially true in the case of Ctenomys and Trinomys. The disparity of modern ctenomyines and octodontines was more than double that of the echimyid subclade A. The highest disparity values correspond to ctenomyines when the modern, extinct, species are included; their disparity is significantly lower when only the living Ctenomys is considered. The lowest disparity values correspond to forest-dwelling echimyids (as anticipated by their relatively more constrained dispersion in the PCA morphospace) which constitute the oldest and most species-rich subclade. 
Table 5.2. Species richness, approximate age and disparity for the studied clades (see Figure 5.I). Species richness updated from Woods and Kilpatrick (2005); molecular datings after Upham and Patterson (2012: fig. 4, table 2).

\begin{tabular}{llll}
\hline Clade & $\begin{array}{l}\text { Species } \\
\text { richness }\end{array}$ & $\begin{array}{l}\text { Clade age fossils/ } \\
\text { molecules }(\mathrm{Ma})\end{array}$ & $\begin{array}{l}\text { Disparity } \\
\text { (Foote's } F \text { ) }\end{array}$ \\
\hline $\begin{array}{l}\text { Echimyidae } \\
\text { Subclade A (mainly forest } \\
\text { environments) }\end{array}$ & 73 & $26.0 / \mathrm{I} 7.0$ & 0.0039 \\
$\begin{array}{l}\text { Subclade B (mainly open } \\
\text { environments) }\end{array}$ & $\mathrm{I} 4$ & $26.0 / \mathrm{I} 6.0$ & $0.004 \mathrm{I}$ \\
$\begin{array}{l}\text { Octodontidae } \\
\text { Crown Octodontinae }\end{array}$ & $\mathrm{I} 3$ & $7.0 / 9.0$ & \\
$\quad \begin{array}{l}\text { Modern Ctenomyinae } \\
\text { Crown Ctenomyinae }\end{array}$ & 69 & $6.4 /-$ & 0.0084 \\
\hline
\end{tabular}

When the species from forest environments, independent of their phylogeny, are compared to the non-forest-dwelling taxa, the disparity of the latter $(F=0.0088)$ is more than double that of forest species $(F=0.0036)$.

Even though formal analyses of rates of evolution, assessing the influence of phylogenetic structure in a taxonomically wider sample (e.g. Collar et al., 2005; O'Meara et al., 2006), are still needed, it is nonetheless clear that higher rates of morphological change occur in modern octodontids, irrespective of species richness. The fossil record of modern ctenomyines is an example of how this could happen. Ctenomyines became differentiated in the Pampasia. Fossil-bearing beds favourable from a taphonomic, geographic and temporal viewpoint, such as the late Miocene Cerro Azul Formation and the coastal Plio-Pleistocene deposits in central Argentina, show that the modernisation of ctenomyines involved intense anagenesis (Figure 5.3). †Actenomys priscus and $\dagger$ Eucelophorus chapalmalensis are the results of directional evolution in lineages with no evidence of cladogenesis (phyletic evolution, in part, Simpson, I953: 384-385; gradual directional change, Rasskin-Gutman and Esteve-Altava, 2008: fig. I; see Verzi, I999; 2008; Verzi et al., 2004), and their contribution to the disparity of ctenomyines is a product of the build-up of changes throughout a period equivalent to that of the cladogenesis of the highly polytypic Ctenomys.

The different patterns of variation here described for modern octodontoids were already reflected in their contrasting taxonomic histories. The supraspecific octodontid taxa recognised on the basis of their morphology have remained stable. The relationship between the two major clades has been recognised through morphology, fossils and molecules (Simpson, I945; Honeycutt et al., 2003; Verzi et al., 20I4), although without agreement regarding the taxonomic rank assigned to both lineages (familial hierarchy, Octodontidae and Ctenomyidae, is currently accepted in neontology). In contrast to this stability, molecular studies of echimyids (Lara et al., I996; Leite and Patton, 2002; Galewski et al., 2005; Fabre et al., 2013) have not been able to recover the subfamilies previously 


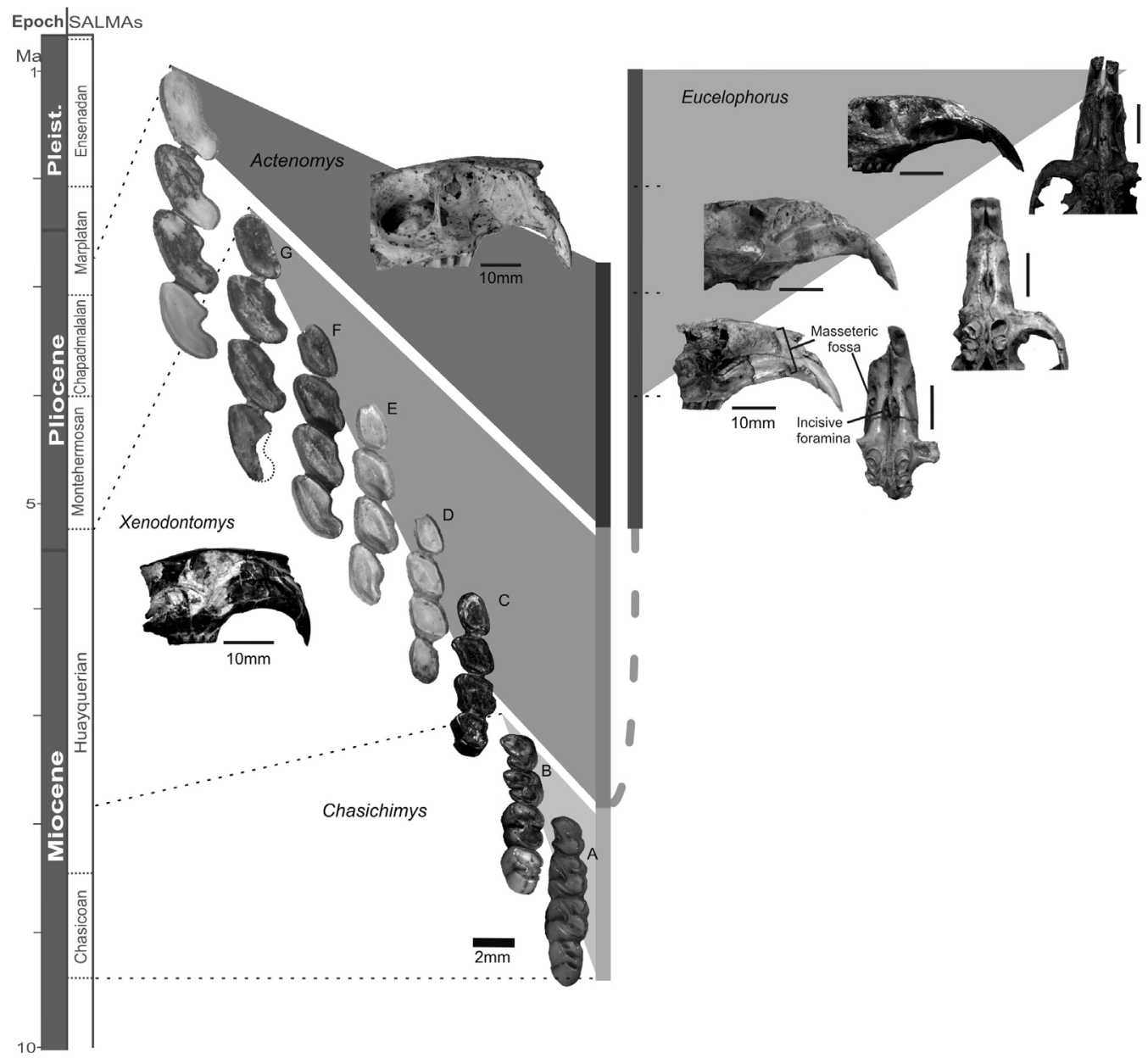

Figure 5.3 Directional gradual evolution in $\uparrow$ Chasichimys- $\uparrow$ Xenodontomys $-\uparrow$ Actenomys priscus (Chasicoan-Marplatan) and $\uparrow$ Eucelophorus chapalmalensis (Montehermosan-Ensenadan) lineages. In the first lineage (left), note the simplification of the occlusal surface (coupled with increased hypsodonty) and subsequent elongation of the occlusal outline, and overall size increase; in $\uparrow$ Eucelophorus (right), the rostrum becoming longer, lower and more procumbent, the masseteric fossa deepening, and the incisive foramina becoming reduced. Occlusal figures correspond to left dp4-m3. A,B: $\dagger$ Chasichimys scagliai; C,D: $\uparrow$ Xenodontomys simpsoni; E,F: $\uparrow$ Xenodontomys ellipticus; G: $\uparrow$ Xenodontomys elongatus (see Verzi et al., 2004).

recognised through the morphological approach of alpha systematics (Woods and Kilpatrick, 2005) as monophyletic groups. In addition, echimyid systematics at the genus level are still in a state of flux (see Emmons, 2005; Iack-Ximenes et al., 2005). The case of Trinomys and Proechimys is particularly illustrative; molecular phylogenies show that the divergence between these two genera is deep, close to the base of the Echimyidae cladogenesis (Lara et al., 1996; Leite and Patton, 2002; Galewski et al., 2005; Fabre et al., 2013); however, before these results, their strongly conservative morphology (Lara et al., 1996) led to their being considered as congeneric (e.g. Moojen, I948; Pessôa and dos Reis, 2002). 


\section{Cenozoic climatic changes, and geographical and temporal hierarchies of the fossil record}

Rainforests occurred in South America up to high latitudes at least since the Eocene (Burnham and Johnson, 2004), and whereas the long-term global Cenozoic cooling (Denton, I999; Zachos et al., 200I, 2008) caused their retraction toward lower latitudes (Barreda and Palazzesi, 2007), their current condition in northern South America has remained essentially stable throughout the Cenozoic (Colinvaux and De Oliveira, 200I). Conversely, in the south of the continent, the deepening Tertiary cooling and drying trend, combined with local diastrophism corresponding to the Quechua phase of Andean orogeny, gave rise to the development of diverse, more open biomes from the late Miocene (Pascual and Ortiz Jaureguizar, I990; Palazzesi and Barreda, 2007; Le Roux, 20I2).

Differences in the evolutionary patterns of echimyids and octodontids reflect different responses to these Cenozoic environmental changes (Pascual, 1967; Verzi, 2002; Verzi et al., 20I4). Echimyids responded to environmental changes by tracking their original habitats, with their extant representatives primarily occurring in the Amazonian, Andean and Atlantic forests (Fabre et al., 2013), and only a few species having colonised more open areas (Hoffstetter, I986; Verzi et al., 1994; Olivares et al., 2012; Upham and Patterson, 20I2). Octodontids, in contrast, evolved diverse adaptations to the new emerging environments.

Because of the biased distribution of fossil beds in South America (Pascual et al., 1985), octodontoids have an essentially southern fossil record. Our phylogenetic results (including the low $\mathrm{MSM}^{*}$ values) suggest that fossil echimyids were less numerous in these deposits than previously thought (in contrast to octodontids), supporting the idea that the presence of this group in southern South America has always represented an impoverished, marginal sample of its astonishing diversity in the northern tropical areas. Early echimyids from the Oligocene to middle Miocene are related to living arboreal tree rats and bamboo rats from the tropical forests (Figure 5.4; Emmons and Feer, I999). In contrast, since the late Miocene the record is restricted to species related to living fossorial and terrestrial spiny rats (Figure 5.I; Vucetich et al., I997; Olivares et al., 2012) occurring mostly in more open, essentially Chacoan areas (Caatinga, Cerrado and Pantanal), and grasslands (Bonvicino et al., 2008; Catzeflis et al., 2008). The progressive decline of these echimyids in this period, heralding their current absence from southern South America, took place along with a marked turnover in the octodontid record in the area. This turnover comprises radiation of hypsodont species and extinction of lineages with primitive molars (Figure 5.I; Verzi, 2008; Verzi et al., 2orr: fig. 8), marking the beginning of the stage of modernisation of octodontines and ctenomyines. The first appearance of marked desert specialisations among euhypsodont octodontines occurred later, coinciding with the profound global late Pliocene cooling and drying event around 2.5 Ma (Figure 5.r; Verzi, 20or; Verzi and Quintana, 2005 and references therein).

The hierarchy of these clade stages, which follows that of concurrent palaeoenvironmental changes, resulted in the current geographical pattern of octodontoids, in which 


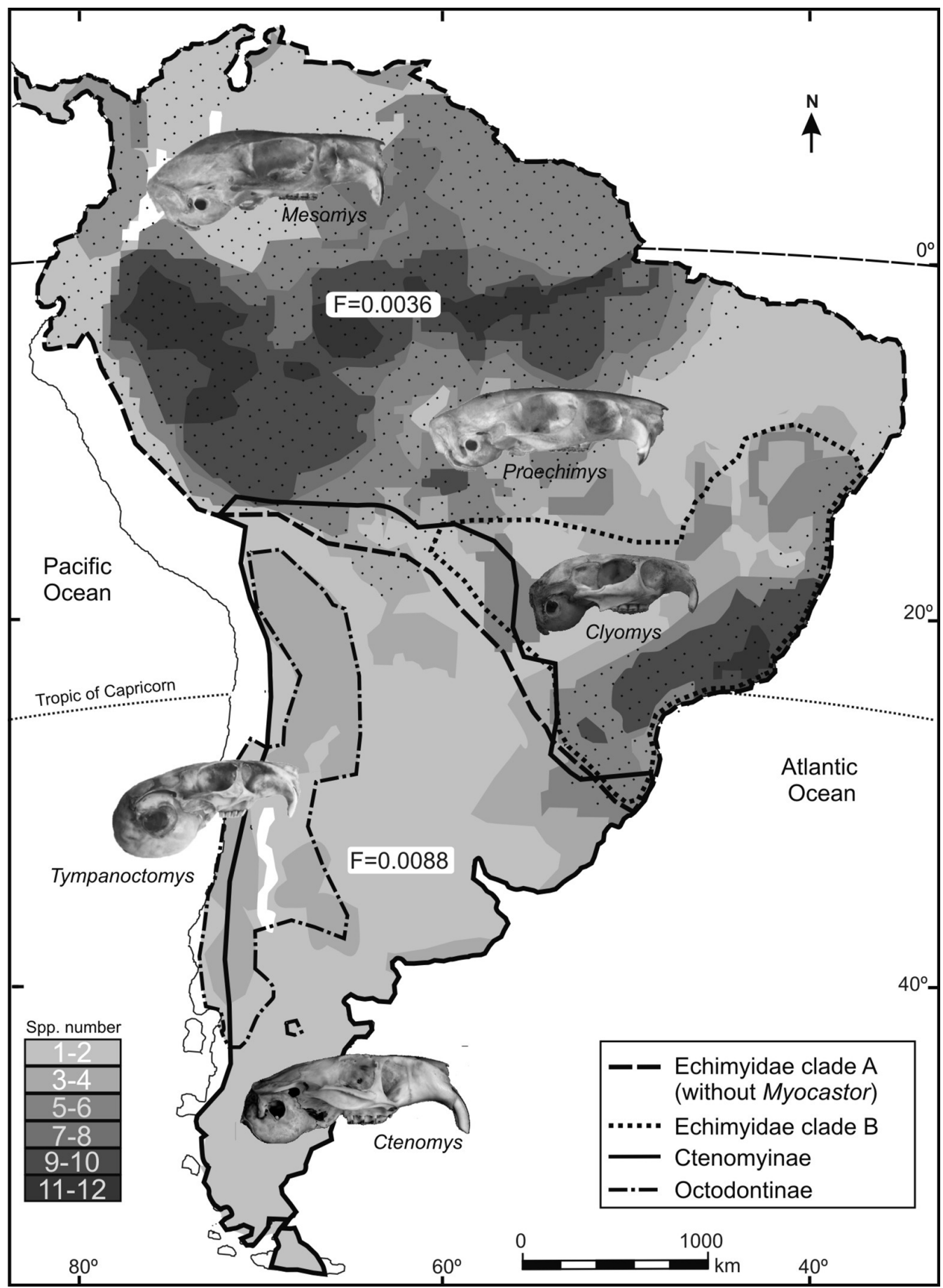

Figure 5.4 Distribution of major clades of echimyids and octodontids showing species density (based on species occurrences in 0.5 by $0.5^{\circ}$ grid cells; modified from Upham and Patterson, 20I2: fig. I), and values of the disparity index (Foote's F) for forest- vs. non-forest-dwelling representatives (see text). Dotted areas indicate distribution of tropical and subtropical moist forests (after Olson et al., 200I). Illustrated skulls not to scale. 
species adjusted to (in this context) "primitive" northern tropical forests (most of the echimyid subclade A) coexist with those occupying more derived habitats, including Chacoan (most of the echimyid subclade B) and southern mesic scrublands and grasslands (most of the mesic-adapted octodontine subclade F), and the more recently arisen desert environments (desert-adapted octodontine subclade $\mathrm{E}$ ).

Such a pattern is not exclusive to octodontoids. In this respect, Janis (200I: III) points out that: "Differences between early Tertiary and present-day mammals are largely the result of a change from equable, globally tropical conditions to a cooler, drier, and more climatically zoned world. Eocene-like mammals remain in the restricted equatorial forests (...) while some extreme specialists have evolved adaptations to environmental conditions unique to the past few million years ...". As is clear from this statement, the temporal and spatial dimensions of this pattern are associated with the vector that represents morphology.

\section{Structure of disparity. The importance of the anagenetic perspective for evolutionary generalisations}

Evolutionary generalisations about the origin and dynamics of biological diversity are among the most revisited, especially with the aim of understanding the processes that generate and maintain high species richness in the tropics (Chown and Gaston, 2000; Wiens and Donoghue, 2004; Jablonski et al., 2006; Mittelbach et al., 2007; Weir and Schluter, 2007; Arita and Vázquez-Domínguez, 2008; Buckley et al., 2010; Hoorn et al., 20Iо; Davies et al., 20II; Rull, 20II). The evolutionary dynamics of other components of diversity, such as morphology (i.e. disparity, Roy and Foote, I997; e.g. Shepherd, I998), or function (Safi et al., 20II), remain less well known, partly because species richness is not an adequate metric to explain them (Jablonski, 2009: 479). In this regard, whether the high tropical diversity is explained by a higher pure speciation or net (relative to extinction) diversification rate, or by a greater time for diversification (see review in Mittelbach et al., 2007), the morphological similarity generally associated with this diversity is a counterintuitive product of these processes, at least in terrestrial faunas. Eldredge (1996: 52-53) explained this paradox of the punctuated equilibria model, which assumes that morphological change is linked to speciation, by proposing that successful speciation in the tropics requires less adaptive change. Likewise, Safi et al. (20II) showed that the high levels of speciation in the tropics seem to produce many species with "conserved niches", resulting in a higher degree of functional redundancy.

It is possible to analyse patterns such as those mentioned from the perspective of the change involved (anagenesis) rather than on the basis of cladogenetic events, as a nonexclusive alternative. Weir and Schluter (2007) detected that a longer lag time between population splitting and species designation (i.e. longer speciation process) in birds and mammals occurs in the tropics and, as a consequence, sister-species pairs from those regions are older. Octodontoids fit this pattern, with most of the tropical forest-dwelling extant species of echimyids being older than those of temperate-areas octodontines and ctenomyines (Upham and Patterson, 20I2: fig. 4). But this generalisation can be extended 
by assessing levels of differentiation that resulted from time-equivalent splits (nodes of similar height): initial splits within genera or small clades of octodontoids in the tropics of South America are of similar age (although not strictly contemporaneous) to those that led to the differentiation of higher taxa in the south. In particular, the beginning of diversification of species within the morphologically similar echimyids Trinomys, Proechimys, Mesomys-Lonchothrix or Dactylomys-Kannabateomys, is close in time to the differentiation of octodontines and ctenomyines, considered as two families in the taxonomy of living mammals (Figure 5.I).

In this generalisation we assume that, beyond ecological circumstances, anagenesis is not restricted to speciation. As stated by Szalay (1999: 52) “. . .rate-varying anagenesis occurs with or without incipient or populational cladogenesis or full or complete cladogenesis, i.e. speciation". The anagenesis that underlies the adaptation of a population, whether it entails the formation of a new species or a long-term gradual directional change giving rise to a new grade (Simpson, 1953), requires cohesion of the evolving lineage (Futuyma, 1987) rather than the contingent perturbation of such cohesion that underlies splitting events. Indeed, diverse interpretations of the formation of species are focused on explaining the processes that lead to cohesion, and not on describing the innumerable contingent circumstances that are able to disturb it (Templeton, I989; Hausdorf, 20II). Thus, the rates of species diversification and morphological change should not be expected to be necessarily coupled (see Kozak et al., 2006; Adams et al., 2009; Jablonski, 2009; Venditti et al., 201I).

When environmental change occurs, species respond by tracking their preferred habitats, adapting or going extinct (Meloro et al., 2013). It is to be expected that taxa which respond by tracking "original" habitats will be morphologically more conservative (Raia et al., 2012) than those that respond by adapting to their new environment, independently of their speciation rates (Table 5.2). This might explain why the origin and differentiation of echimyids are not perceptible as decoupled events, and may furthermore account for the morphological similarity shown by their anciently diverged lineages (Lara et al., I996: 4IO; Da Silva and Patton, I998; Fabre et al., 2013). In octodontines and ctenomyines, the adaptation to new emerging environmental conditions shows stages of southern differentiation that are distinctly decoupled from their respective origins. As in the case of the geographical and temporal dimensions, the hierarchy of these morphological stages follows that of concurrent palaeoenvironmental changes.

Most records of long-term gradual directional change resulting in deep morphological change in octodontoids date from the late Miocene-Pliocene (Verzi et al., 20II), when the already-established cooling and drying trend shows largely narrower oscillations (as represented by the variance of oxygen isotope excursions) than those observed for the succession of ice ages that began in the latest Pliocene (Figure 5.I). Although this remark is here merely exploratory, this is consistent with the model proposed by Sheldon (1996), which predicts that long-term phyletic change requires climatic trends with small-amplitude oscillations. According to this model, such conditions in tropical environments should also favour gradual directional change; possibly, given that the magnitude of environmental change is lower (Colinvaux and De Oliveira, 200I), 
a lower change rate is also to be expected, beyond its assumed greater constancy (as shown by the results of Weir and Schluter, 2007).

Croizat's (1962) dictum "earth and life evolved together" possesses an anagenetic dimension that has been scarcely attended in comparison with a vicariant, or in a broader sense cladogenetic, perspective. This is despite the fact that the former probably necessitates less systematisation of contingent factors to provide explanations. As Jablonski (2009: 478) pointed out, '...one of the most striking facts of the fossil record (...) [is] that evolutionary novelties do not arise randomly in time and space'. Derived environments trigger morphological adaptation, independently of the frequency of cladogenetic events. In the context of the evolutionary history of octodontoids, and even of terrestrial mammals (Janis, 200I), derived environments are represented in the extratropics; thus, regardless of how the latitudinal diversity gradients occur, the extratropics play an important role as a cradle of evolutionary novelties.

In the complex dynamics of the organic world, the immanent (unchangeable, and therefore predictable) properties of matter become manifest through configurational, i.e. historical, circumstances, which are essentially unrepeatable or putatively recurring (Simpson, 1963). In the face of the difficulty of providing laws, the central aim of historical sciences is the search for increasingly wider explanatory generalisations. We believe that mutually dependent cohesion and change (anagenesis) are core concepts to explain the dynamics of life (Templeton, I989; Maynard Smith and Szathmáry, I997: 6-9), which should be more often considered when exploring configurational events in search of patterns.

\section{Summary}

South American Octodontoidea is the most species-rich clade among both extinct and extant hystricomorph rodents. The evolutionary histories of its two major groups, Octodontidae and Echimyidae, are differentially linked to the main Cenozoic palaeoenvironmental changes. According to a combined parsimony analysis of morphological and molecular data, they represent sister families, which were already separated in the late Oligocene, as well as the two major subclades comprised by each one. Whereas the octodontid subclades Octodontinae and Ctenomyinae show progressive stages of differentiation (modernisation) since the late Miocene, similar phases uncoupled from their respective origins are not recognisable in the echimyid subclades. The greater spread of modern octodontids in the morphospace of skull variation, and their greater relative disparity, independent of age and species richness, result from the abovementioned stages of differentiation and imply specialisation to open environments. Thus, the history of octodontoids suggests that the acquisition of evolutionary novelties is linked to the progressive emergence of new environments, and this link is manifested through different hierarchies, i.e. geographic, temporal and anagenetic (amount of change, irrespective of cladogenetic events). For these rodents, as well as for other terrestrial mammals, derived environments occur out of the tropics, thus highlighting the importance of the extratropics as a cradle of evolutionary novelties. 


\section{Acknowledgements}

We thank the following institutions for allowing access to materials under their care: Colección Boliviana de Fauna, La Paz, Bolivia (CBF); Instituto y Museo de Ciencias Naturales, San Juan, Argentina (IMCN); Museo Argentino de Ciencias Naturales "Bernardino Rivadavia", Buenos Aires, Argentina (MACN); Museo de Ciencias Naturales de Mar del Plata "Lorenzo Scaglia”, Mar del Plata, Argentina (MMPMA, MMP-M); Museo de La Plata, La Plata, Argentina (MLP); Museu de Zoologia, Universidade de São Paulo, São Paulo, Brasil (MZUSP); Museu de Zoologia, Universidade Federal de Bahia, Bahia, Brasil (UFBA); Museu Nacional, Universidade Federal do Rio de Janeiro, Rio de Janeiro, Brasil (MN); Museum of Vertebrate Zoology, University of California, Berkeley, USA (MVZ); Universidade de Brasília, Brasília, Brasil (UnB). We are especially grateful to the editors, P. Cox and L. Hautier, for the invitation to contribute to this volume. We thank A. Álvarez, I. Perez and D. Pol for their valuable suggestions regarding methodological aspects; J. Zachos for allowing use of his original isotope dataset; D. Pol for providing the TNT script for MSM*. We thank A. Vassallo and an anonymous reviewer for critical reading of the ms. This chapter is a contribution to projects CONICET PIP o270 and ANPCyT PICT 20I2-II5o.

\section{REFERENCES}

Adams, D. C., Berns, C. M., Kozak, K. H. and Wiens, J. J. (2009). Are rates of species diversification correlated with rates of morphological evolution? Proceedings of the Royal Society B, 276, $2729-2738$.

Antoine, P.-O., Marivaux, L., Croft, D. A., et al. (2012). Middle Eocene rodents from Peruvian Amazonia reveal the pattern and timing of caviomorph origins and biogeography. Proceedings of the Royal Society B, 279, I319-I326.

Arakaki, M., Christin, P.-A., Nyffeler, R. et al. (20II). Contemporaneous and recent radiations of the world's major succulent plant lineages. Proceedings of the National Academy of Sciences, USA, ro8, $8379-8384$.

Arita, H. T. and Vázquez-Domínguez, E. (2008). The tropics: cradle, museum or casino? A dynamic null model for latitudinal gradients of species diversity. Ecology Letters, II, 653-663.

Arnal, M. and Pérez, M. E. (20I3). A new acaremyid rodent (Hystricognathi: Octodontoidea) from the middle Miocene of Patagonia (South America) and considerations on the early evolution of Octodontoidea. Zootaxa, 36r6, II9-I34.

Barreda, V. and Palazzesi, L. (2007). Patagonian vegetation turnovers during the Paleogene-Early Neogene: origin of arid-adapted floras. Botanical Review, 73, 31-50.

Benton, M. J. and Donoghue, P. C. J. (2007). Paleontological evidence to date the tree of life. Molecular Biology and Evolution, 24, 26-53.

Bertelli, S. and Giannini, N. P. (2005). A phylogeny of extant penguins (Aves: Sphenisciformes) combining morphology and mitochondrial sequences. Cladistics, 2I, 209-239.

Bertrand, O. C., Flynn, J. J., Croft, D. A. and Wyss, A. R. (2012). Two new taxa (Caviomorpha, Rodentia) from the Early Oligocene Tinguiririca Fauna (Chile). American Museum Novitates, $3750,{ }^{-}-36$. 
Bonvicino, C. R., de Oliveira J. A. and D'Andrea P. S. (2008). Guia dos roedores do Brasil, com chaves para gêneros baseadas em caracteres externos. Rio de Janeiro: Centro Pan-Americano de Febre Aftosa.

Bookstein, F. L. (1997). Landmark methods for forms without landmarks: morphometrics of group differences in outline shape. Medical Image Analysis, I, 225-243.

Briggs, D. E. G. and Fortey, R. A. (2005). Wonderful strife: systematics, stem groups, and the phylogenetic signal of the Cambrian radiation. Paleobiology, 3I, 94-II2.

Buckley, L. B., Davies, T. J., Ackerly, D. D., et al. (20ro). Phylogeny, niche conservatism and the latitudinal diversity gradient in mammals. Proceedings of The Royal Society B, 277, 2I3I-2138.

Burnham, R. J. and Johnson, K. R. (2004). South American palaeobotany and the origins of Neotropical rainforests. Philosophical Transactions of The Royal Society of London B, 359, I595-1610.

Carvalho, G. A. S. and Salles, O. L. (2004). Relationships among extant and fossil echimyids (Rodentia: Hystricognathi). Zoological Journal of the Linnean Society, 142, 445-477.

Catzeflis, F., Patton, J., Percequillo, A., Bonvicino, C. and Weksler, M. (2008). Euryzygomatomys spinosus. In: IUCN 2013. IUCN Red List of Threatened Species. Version 2013.I. www. iucnredlist.org.

Chown, S. L. and Gaston, K. J. (2000). Areas, cradles and museums: the latitudinal gradient in species richness. Trends in Ecology and Evolution, 15, 3II-315.

Coddington, J. A. and Scharff, N. (1994). Problems with zero-length branches. Cladistics, Io, 415-423.

Colinvaux, P. A and De Oliveira, P. E. (200r). Amazon plant diversity and climate through the Cenozoic. Palaeogeography, Palaeoclimatology, Palaeoecology, r66, 5I-63.

Collar, D. C., Near, T. J. and Wainwright, P. C. (2005). Comparative analysis of morphological diversity: does disparity accumulate at the same rate in two lineages of centrarchid fishes? Evolution, 59, I783-I794.

Croizat, L. (1962). Space, Time, Form: The Biological Synthesis. Netherlands: Drukkerij Salland Deventer.

Da Silva, M. N. and Patton, J. L. (1998). Molecular phylogeography and the evolution and conservation of Amazonian mammals. Molecular Ecology, 7, 475-486.

Davies, T. J., Buckley, L. B., Grenyer, R. and Gittleman, J. L. (20II). The influence of past and present climate on the biogeography of modern mammal diversity. Philosophical Transactions of The Royal Society B, 366, 2526-2535.

Denton, G. H. (1999). Cenozoic climate change. In African Biogeography, Climate Change, and Human Evolution, eds. T. G. Bromage and F. Schrenk. New York: Oxford University Press, pp. 94-II4.

Donoghue, P. C. J. (2005). Saving the stem group-a contradiction in terms? Paleobiology, 3I, 553-558.

Eisenberg, J. F. and Redford, K. H. (1999). Mammals of the Neotropics. The Central Neotropics: Ecuador, Peru, Bolivia, Brazil. Chicago: University of Chicago Press.

Eldredge, N. (1996). Hierarchies in macroevolution. In Evolutionary Paleobiology, eds. D. Jablonsky, D. H. Erwin and J. H. Lipps. Chicago: University of Chicago Press, pp. 42-6I.

Emmons, L. H. (2005). A revision of the genera of arboreal Echimyidae (Rodentia: Echimyidae, Echimyinae), with descriptions of two new genera. In Mammalian Diversification: from Chromosomes to Phylogeography (a Celebration of the Career of James L. Patton), eds. E. A. Lacey and P. Myers. Berkeley: University of California Press, pp. 247-309.

Emmons, L. H. and Feer, F. (1999). Neotropical Rainforest Mammals: a Field Guide. Chicago: University of Chicago Press.

Fabre, P.-H., Galewski, T., Tilak, M. and Douzery, E. J. P. (2013). Diversification of South American spiny rats (Echimyidae): a multigene phylogenetic approach. Zoologica Scripta, 42, II7-I34. 
Foote, M. (1993). Contributions of individual taxa to overall morphological disparity. Paleobiology, I9, 403-319.

Futuyma, D. J. (1987). On the role of species in anagenesis. The American Naturalist, 130, 465-473.

Galewski, T., Mauffrey, J. F., Leite, Y. L. R., et al. (2005). Ecomorphological diversification among South American spiny rats (Rodentia: Echimyidae): a phylogenetic and chronological approach. Molecular Phylogenetics and Evolution, 34, 60I-615.

Gallardo, M. H. and Kirsch, J. A. W. (20oI). Molecular relationships among Octodontidae (Mammalia: Rodentia: Caviomorpha). Journal of Mammalian Evolution, 8, 73-89.

Goloboff, P. A., Farris, J. S. and Nixon, K. (2008a). TNT: Tree Analysis Using New Technology, Version I.I. Available at: http://www.zmuc.dk/public/phylogeny/tnt.

Goloboff, P. A., Farris, J. S. and Nixon, K. (2008b). TNT, a free program for phylogenetic analysis. Cladistics, 24, 774-786.

Gradstein, F. M., Ogg, J. G. and Van Kranendonk, M. (2008). On the Geologic Time Scale 2008. Newsletters on Stratigraphy, 43, 5-I3.

Hausdorf, B. (20II). Progress toward a general species concept. Evolution, 65, 923-93I.

Hautier, L., Lebrun, R. and Cox, P. G. (2012). Patterns of covariation in the masticatory apparatus of hystricognathous rodents: implications for evolution and diversification. Journal of Morphology, 273, I319-I337.

Helgen, K. M. (20II). The mammal family tree. Science, 334, 458-459.

Hennig, W. (1965). Phylogenetic systematics. Annual Review of Entomology, ro, 97-II6.

Hoffstetter, R. (1986). High Andean mammalian faunas during the Plio-Pleistocene. In High Altitude Tropical Biogeography, eds. F. Vuilleumier and M. Monasterio. Oxford: Oxford University Press, pp. $218-245$.

Honeycutt, R. L. (2009). Rodents (Rodentia). In The Timetree of Life, eds. S. B. Hedges and S. Kumar. New York: Oxford University Press, pp. 490-494.

Honeycutt, R. L., Rowe, D. L. and Gallardo, M. H. (2003). Molecular systematics of the South American caviomorph rodents: relationships among species and genera in the family Octodontidae. Molecular Phylogenetics and Evolution, 26, 476-489.

Hoorn, C., Wesselingh, F. P., Ter Steege, H., et al. (2010). Amazonia through time: Andean uplift, climate change, landscape evolution, and biodiversity. Science, 330, 927-93I.

Iack-Ximenes, G. E., De Vivo, M. and Percequillo, A. R. (2005). A new genus for Loncheres grandis Wagner, I845, with taxonomic comments on other arboreal echimyids (Rodentia, Echimyidae). Arquivos do Museu Nacional, Rio de Janeiro, 63, 89-II2.

Jablonski, D. (2009). Paleontology in the twenty-first century. In The Paleobiological Revolution. Essays on the Growth of Modern Paleontology, eds. D. Sepkoski and M. Ruse. Chicago and London: The University of Chicago Press, pp. 471-517.

Jablonski, D., Roy, K. and Valentine, J. W. (2006). Out of the tropics: evolutionary dynamics of the

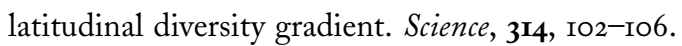

Janis, C. M. (20or). Radiation of Tertiary mammals. In Palaeobiology II, ed. D. E. G. Briggs and P. R. Crowther. Oxford: Blackwell Publishing, pp. Iо9-II2.

Klingenberg, C. P. (2OII). MORPHOJ: an integrated software package for geometric morphometrics. Molecular Ecology Resources, II, 353-357.

Kozak, K. H., Weisrock, D. W. and Larson, A. (2006). Rapid lineage accumulation in a non-adaptive radiation: phylogenetic analysis of diversification rates in eastern North American woodland salamanders (Plethodontidae: Plethodon). Proceedings of the Royal Society B, 273, 539-546. 
Lara, M. C., Patton, J. L. and Da Silva, M. N. (1996). The simultaneous diversification of South American echimyid rodents (Hystricognathi) based on complete cytochrome b sequences. Molecular Phylogenetics and Evolution, 5, 403-4I3.

Lay, D. M. (1972). The anatomy, physiology, functional significance and evolution of specialized hearing organs of gerbilline rodents. Journal of Morphology, 138, 4I-12O.

Le Roux, J. P. (20I2). A review of Tertiary climate changes in southern South America and the Antarctic Peninsula. Part 2: continental conditions. Sedimentary Geology, 247-248, 2I-38.

Leite, Y. L. R. and Patton J. L. (2002). Evolution of South American spiny rats (Rodentia, Echimyidae): the star phylogeny hypothesis revisited. Molecular Phylogenetics and Evolution, 25, $455^{-464}$.

Lessa, E. P., Vassallo, A. I., Verzi, D. H. and Mora, M. (2008). Evolution of morphological adaptations for digging in living and extinct ctenomyid and octodontid rodents. Biological Journal of the Linnean Society, 95, 267-283

Mares, M. A. and Ojeda, R. A. (1982). Patterns of diversity and adaptation in South American hystricognath rodents. In Mammalian Biology in South America, eds. M. A. Mares and H. Genoways. Pittsburgh, PA, USA: Special Publication Pymatuning Laboratory of Ecology 6. University of Pittsburgh, pp. 393-432.

Maynard Smith, J. and Szathmáry, E. (1997). The Major Transitions in Evolution. Oxford: Oxford University Press.

McKenna, M. C. and Bell, S. K. (1997). Classification of Mammals above the Species Level. New York: Columbia University Press.

Meloro, C., Cáceres, N., Carotenuto, F., et al. (2013). In and out the Amazonia: evolutionary ecomorphology in howler and capuchin monkeys. Evolutionary Biology, 4I, 38-5I.

Mittelbach, G. G., Schemske, D. W., Cornell, H. V., et al. (2007). Evolution and the latitudinal diversity gradient: speciation, extinction and biogeography. Ecology Letters, 10, 315-331.

Moojen, J. (1948). Speciation in the Brazilian spiny rats (genus Proechimys, family Echimyidae). University of Kansas Publications, Museum of Natural History, I, 30I-406.

Norell, M. A. (1992). Taxic origin and temporal diversity: the effect of phylogeny. In Extinction and Phylogeny, eds. M. J. Novacek and Q. D. Wheeler. New York: Columbia University Press, pp. ${ }^{88-\mathrm{II} 8 .}$

Ojeda, A. A., Novillo, A., Ojeda R. A. and Roig-Juñent, S. (2013). Geographical distribution and ecological diversification of South American octodontid rodents. Journal of Zoology, 289, 285-293.

Ojeda, R. A. and Tabeni, S. (2009). The mammals of the Monte Desert revisited. Journal of Arid Environments, 73, I73-I8I.

Ojeda, R. A., Borghi, C. E., Diaz, G. B., et al. (I999). Evolutionary convergence of the highly adapted desert rodent Tympanoctomys barrerae (Octodontidae). Journal of Arid Environments, 4I, 443-452.

Olivares, A. I., Verzi, D. H., Vucetich, M. G. and Montalvo, C. I. (20I2). Phylogenetic affinities of the late Miocene echimyid $†$ Pampamys and the age of Thrichomys (Rodentia, Hystricognathi). Journal of Mammalogy, 92, 76-86.

Olson D. M., Dinerstein, E., Wikramanayake, E. D., et al. (200I). Terrestrial ecoregions of the world: a new map of life on earth. BioScience, 5I, 933-938.

O’Meara, B. C., Ané, C., Sanderson, M. J. and Wainwright, P. C. (2006). Testing for different rates of continuous trait evolution using likelihood. Evolution, 6o, 922-933.

Opazo, J. C. (2005). A molecular timescale for caviomorph rodents (Mammalia, Hystricognathi). Molecular Phylogenetics and Evolution, 37, 932-937. 
Palazzesi, L. and Barreda, V. (2007). Major vegetation trends in the Tertiary of Patagonia (Argentina): a qualitative paleoclimatic approach based on palynological evidence. Flora, 202, 328-337.

Pascual, R. (1967). Los roedores Octodontoidea (Caviomorpha) de la Formación Arroyo Chasicó (Plioceno inferior) de la Provincia de Buenos Aires. Revista del Museo de La Plata, Paleontología, $5,259^{-282 .}$

Pascual, R. and Ortiz Jaureguizar, E. (1990). Evolving climates and mammal faunas in Cenozoic South America. Journal of Human Evolution, 19, 23-60.

Pascual, R., Vucetich, M. G., Scillato-Yané and G. J., Bond, M. (1985). Main pathways of mammalian diversification in South America. In The Great American Biotic Interchange: Series Topics in Geobiology 4, eds. F. G. Stehli and S. D. Webb. New York: Plenum Press, pp. 219-247.

Patterson, B. and Wood, A. E. (I982). Rodents from the Deseadan Oligocene of Bolivia and the relationships of the Caviomorpha. Bulletin of the Museum of Comparative Zoology, 149, $37 \mathrm{I}^{-} 543$.

Patterson, C. (1993a). Bird or dinosaur? Nature, 365, 2I-22.

Patterson, C. (1993b). Naming names. Nature, 366, 518.

Pessôa, L. M. and dos Reis, S. F. (2002). Proechimys albispinus. Mammalian Species, 693, I-3.

Pol, D. and Norell, M. A. (20or). Comments on the Manhattan Stratigraphic Measure. Cladistics, I7, $285^{-289}$.

Pol, D., Norell, M. A. and Siddall, M. E. (2004). Measures of stratigraphic fit to phylogeny and their sensitivity to tree size, tree shape, and scale. Cladistics, 20, 64-75.

Raia, P., Passaro, F., Fulgione, D. and Carotenuto, F. (2012). Habitat tracking, stasis and survival in Neogene large mammals. Biology Letters, 8, 64-66.

Rasskin-Gutman, D. and Esteve-Altava, B. (2008). The multiple directions of evolutionary change. BioEssays, 30, 52I-525.

Redford, K. H. and Eisenberg, J. F. (1992). Mammals of the Neotropics. The Southern Cone: Chile, Argentina, Uruguay, Paraguay. Chicago: University of Chicago Press.

Reig, O. A. (1986). Diversity patterns and differentiation of high Andean rodents. In High Altitude Tropical Biogeography, eds. F. Vuilleumier and M. Monasterio. Oxford: Oxford University Press, pp. $404-439$.

Reig, O. A. (1989). Karyotypic repatterning as one triggering factor in cases of explosive speciation. In Evolutionary Biology of Transient Unstable Populations, ed. A. Fontdevila, Berlin: SpringerVerlag, pp. 246-289.

Rohlf, F. J. (2008). Tpsdig, Version 2.I2; tpsrelw, Version I.46. Stony Brook, NY: State University of New York at Stony Brook, Available at: http://life.bio.sunysb.edu/morph/

Rohlf, F. J. (20IO). TPSRelw I.49. tps series software available at http://life.bio.sunysb.edu/morph.

Rowe, D. L., Dunn, K. A., Adkins, R. M. and Honeycutt, R. L. (2010). Molecular clocks keep dispersal hypotheses afloat: evidence for trans-Atlantic rafting by rodents. Journal of Biogeography, 37, 305-324.

Roy, K. and Foote, M. (1997). Morphological approaches to measuring biodiversity. Trends in Ecology and Evolution, I2, 277-28I.

Rull, V. (20II). Neotropical biodiversity: timing and potential drivers. Trends in Ecology and Evolution, 26, 508-513.

Safi, K., Cianciaruso, M. V., Loyola, R. D., et al. (20II). Understanding global patterns of mammalian functional and phylogenetic diversity. Philosophical Transactions of The Royal Society B, $\mathbf{3 6 6}$, $2536-2544$. 
Sheets, H. D. (20I0-20I2). Integrated Morphometrics Package (IMP) 7, available at http://www3. canisius.edu/ sheets/imp7.htm.

Sheldon, P. R. (1996). Plus ça change - a model for stasis and evolution in different environments. Palaeogeography, Palaeoclimatology, Palaeoecology, 127, 209-227.

Shepherd, U. L. (1998). A comparison of species diversity and morphological diversity across the North American latitudinal gradient. Journal of Biogeography, 25, 19-29.

Simpson, G. G. (1945). The principles of classification and a classification of mammals. Bulletin of the American Museum of Natural History, 85, I-350.

Simpson, G. G. (1953). The Major Features of Evolution. New York: Columbia University Press.

Simpson, G. G. (1963). Historical science. In The Fabric of Geology, ed. C. Albritton. California, USA: Freeman, pp. 24-48.

Smith, A. B. (1994). Systematics and the Fossil Record: Documenting Evolutionary Patterns. London: Blackwell Scientific Publications.

Stein, B. R. (2000). Morphology of subterranean rodents. In Life Underground. The Biology of Subterranean Rodents, eds. A. E., Lacey, J. L. Patton and G. N. Cameron. Chicago: University of Chicago Press, pp. 19-6r.

Steiper, M. E. and Young, N. M. (2008). Timing primate evolution: lessons from the discordance between molecular and paleontological estimates. Evolutionary Anthropology, I7, I79-188.

Szalay, F. S. (1999). Paleontology and macroevolution. On the theoretical conflict between an expanded synthesis and hierarchic punctuationism. In: African Biogeography, Climate Change, and Human Evolution, eds. T. G. Bromage and F. Schrenk. New York: Oxford University Press, pp. 35-56.

Templeton, A. R. (1989). The meaning of species and speciation: a genetic perspective. In Speciation and its Consequences, eds. D. Otte and J. A. Endler. Sunderland, Massachusetts: Sinauer Associates, pp. $3^{-27}$.

Thompson, J. D., Gibson, T. J., Plewniak, F., et al. (1997). The CLUSTAL_X windows interface: flexible strategies for multiple sequence alignment aided by quality analysis tools. Nucleic Acids Research, 25, 4876-4882.

Upham, N. S. and Patterson, B. D. (2012). Diversification and biogeography of the Neotropical caviomorph lineage Octodontoidea (Rodentia: Hystricognathi). Molecular Phylogenetics and Evolution, 63, 4I7-429.

Venditti, C., Meade, A. and Pagel, M. (20II). Multiple routes to mammalian diversity. Nature, 479, 393-396.

Verzi, D. H. (1999). The dental evidence on the differentiation of the ctenomyine rodents (Caviomorpha, Octodontidae, Ctenomyinae). Acta Theriologica, 44, 263-282.

Verzi, D. H. (20or). Phylogenetic position of Abalosia and the evolution of the extant Octodontinae (Rodentia, Caviomorpha, Octodontidae). Acta Theriologica, 46, 243-268.

Verzi, D. H. (2002). Patrones de evolución morfológica en Ctenomyinae (Rodentia, Octodontidae). Mastozoología Neotropical, 9, 309-328.

Verzi, D. H. (2008). Phylogeny and adaptive diversity of rodents of the family Ctenomyidae (Caviomorpha): delimiting lineages and genera in the fossil record. Journal of Zoology, 274, 386-394.

Verzi, D. H. and Olivares A. I. (2006). Craniomandibular joint in South American burrowing rodents (Ctenomyidae): adaptations and constraints related to a specialised mandibular position in digging. Journal of Zoology, 270, 488-501.

Verzi, D. H. and Quintana, C. A. (2005). The Caviomorph rodents from the San Andrés Formation, east-central Argentina, and global Late Pliocene climatic change. Palaeogeography,

Palaeoclimatology, Palaeoecology, 219, 303-320. 
Verzi, D. H., Vucetich, M. G. and Montalvo, C. I. (1994). Octodontid-like Echimyidae (Rodentia): an upper Miocene episode in the radiation of the family. Palaeovertebrata, 23, I99-2IO.

Verzi, D. H., Vieytes, E. C. and Montalvo, C. I. (2004). Dental evolution in Xenodontomys and first notice on secondary acquisition of radial enamel in rodents (Rodentia, Caviomorpha, Octodontidae). Geobios, 37, 795-806.

Verzi, D. H., Vieytes, E. C. and Montalvo, C. I. (20II). Dental evolution in Neophanomys (Rodentia, Octodontidae) from the late Miocene of central Argentina. Geobios, 44, 62I-633.

Verzi, D. H., Olivares, A. I. and Morgan, C. C. (20r4). Phylogeny, evolutionary patterns and timescale of South American octodontoid rodents. The importance of recognising morphological differentiation in the fossil record. Acta Palaeontologica Polonica, 59, 757-769.

Vieytes, E. C., Morgan, C. C. and Verzi, D. H. (2007). Adaptive diversity of incisor enamel microstructure in South American burrowing rodents (family Ctenomyidae, Caviomorpha). Journal of Anatomy, 2II, 296-302.

Vrba, E. S., Denton, G. H., Partridge, T. C. and Burckle, L. H.. (eds.) (r995). Paleoclimate and Evolution with Emphasis on Human Origins. New Haven: Yale University Press.

Vucetich, M. G. and Kramarz, A. G. (2003). New Miocene rodents from Patagonia (Argentina) and their bearing on the early radiation of the octodontoids (Hystricognathi). Journal of Vertebrate Paleontology, 23, 435-444.

Vucetich, M. G., Verzi, D. H. and Tonni, E. P. (1997). Paleoclimatic implications of the presence of Clyomys (Rodentia, Echimyidae) in the Pleistocene of central Argentina. Palaeogeography, Palaeoclimatology, Palaeoecology, 128, 207-214.

Vucetich, M. G., Verzi, D. H. and Hartenberger, J.-L. (I999). Review and analysis of the radiation of the South American Hystricognathi (Mammalia, Rodentia). Comptes Rendus de L'Academie des Sciences, Série IIa/Sciences de la Terre et des Planètes. Paléontologie, 329, 763-769.

Weir, J. T. and Schluter, D. (2007). The latitudinal gradient in recent speciation and extinction rates of birds and mammals. Science, 315, 1574-1576.

Wiens, J. J. and Donoghue, M. J. (2004). Historical biogeography, ecology and species richness. Trends in Ecology and Evolution, 19, 639-644.

Wilson, L. A. B. and Sánchez-Villagra, M. R. (2010). Diversity trends and their ontogenetic basis: an exploration of allometric disparity in rodents. Proceedings of the Royal Society B, 277, I227-I234.

Wood, A. E. and Patterson, B. (I959). Rodents of the Deseadan Oligocene of Patagonia and the beginnings of South American rodent evolution. Bulletin of the Museum of Comparative Zoology, I20, 279-428.

Woods, C. A. and Kilpatrick, C. W. (2005). Infraorder Hystricognathi Brandt, I855. In Mammal Species of the World, eds. D. E. Wilson and D. M. Reeder. Baltimore MD: Johns Hopkins University Press, pp. 1538-1600.

Zachos, J., Pagani, M., Sloan, L., Thomas, E. and Billups, K. (20oI). Trends, rhythms, and aberrations in global climate $65 \mathrm{Ma}$ to present. Science, 292, 686-693.

Zachos, J. C., Dickens, G. R. and Zeebe, R. E. (2008). An early Cenozoic perspective on greenhouse warming and carbon-cycle dynamics. Nature, 45I, 279-283. 


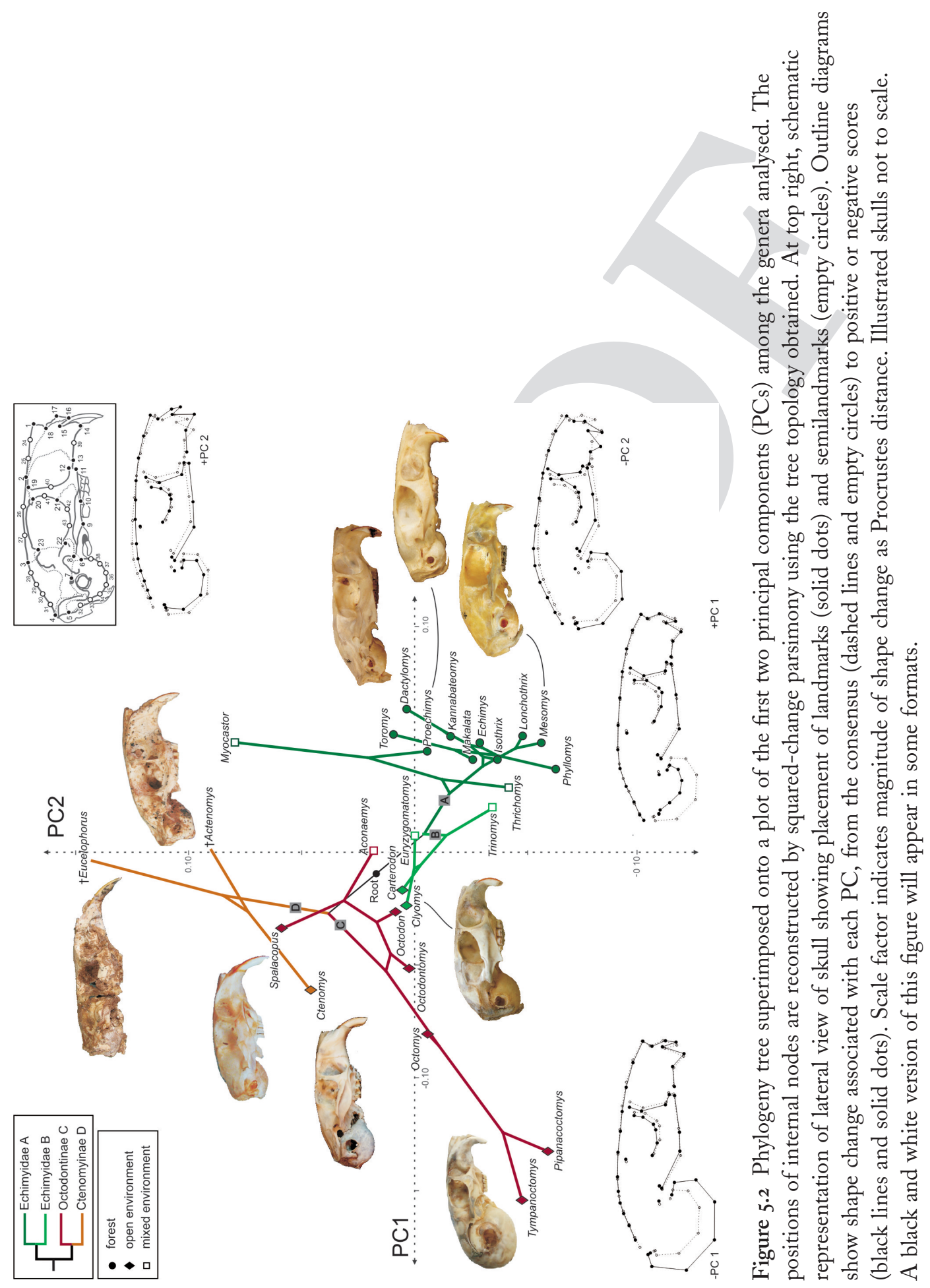

